\title{
Physical and Psycho-Physical Characteristics of Female on Developed Pedal Operated Rotary Maize Sheller in Akola Region
}

\author{
Kanchan V. Gedam* and S.K. Thakare \\ Dr. Panjabrao Deshmukh Krishi Vidyapeeth, Akola- 444104, India \\ *Corresponding author
}

\section{A B S T R A C T}

\section{Keywords}

Anthropometry, Percentile, Maize shelling, Stature

Article Info

Accepted:

15 May 2019

Available Online:

1 June 2019

\begin{abstract}
Maize is the most important cereal grain in the world, after wheat and rice. According to the survey of existing practices of shelling maize, it was observed that the procedure of shelling maize was very difficult and shelling efficiency was very low. These problems were solved by developing hand operated rotary maize sheller. To assess ergonomical performance of pedal operated rotary maize sheller, the trial was conducted on test set-up for measuring psycho-physical responses, overall discomfort rating and body part discomfort score experienced, so body-part discomfort score and overall discomfort score were found to be 7, 2.88 on pedal operated maize sheller. The body discomfort was mainly experienced at left and right knee, left and right leg, and left and right thigh According to Visual Analogue Discomfort scale the category of the pedal operated maize sheller was found to be "light discomfort" and shelling efficiency and output capacity were found to be $220 \mathrm{~kg} \mathrm{~h}^{-1}$ and $98.09 \%$ on hand operated maize sheller.
\end{abstract}

\section{Introduction}

Maize is the most important cereal grain in the world, after wheat and rice, providing nutrients for humans and animals and serving as a basic raw material for the production of starch, oil and protein, alcoholic beverages, food sweeteners maltodextrins, corn oil, corn syrup and products of fermentation and distillation industries.

It is also being recently used as biofuel. It is called as "Queen of cereals" and "King of fodder" having high importance in human and animal food because it contains less percent of fat.

\section{Problem statement}

Small land holding farmers in the country deals with many problems arises due to maize shelling

During maize farming because it is tedious and time consuming job to remove the grain from cob.

Keeping the above factors in view, present study was under taken on ergonomical assessment of hand operated rotary maize sheller. 


\section{Statement of the scope}

According to the survey of existing practices of shelling maize, it was observed that the procedure of shelling maize was very difficult and shelling efficiency was very low. These problems were solved by developing hand operated rotary maize sheller. But the working procedure of hand operated maize sheller was not safe and comfortable as operator has to perform the maize shelling operation by rotating a long crank handle in bending posture results in discomfort and fatigue. This method required more energy for work resulting lowest output capacity due to tiredness and drudgery of labour among all de-shellers.

In view of the above focuses on energy considerations which arise from the physiological and psychophysical responses of the rural farmer during operation of the maize sheller, modification in system as to be done to have higher man-machine system efficiency.

Therefore, the ergonomic study of hand maize sheller was felt very necessary for finding and overcoming problem so as to increase the human-machine system efficiency and to improve the operator's health.

\section{Physical response}

Curteon (1947) reported that basal metabolic rate, heart beat rate and oxygen consumption rate are the pertinent parameters for assessing the human energy required for performing various types of operation.

\section{Ergonomical evaluation}

Ramchandra et al., (2008) studied on ergonomic evaluation of different equipment on the basis of energy consumption and disorders caused among agricultural workers compared the foot operated rotary maize sheller are better than bicycle or pedal mode. However, there is lack of information on comparative evaluation of different modes of mechanism to produce rotary motion by farm workers in terms of energy consumption and postural discomfort (Solanki et al., 2006; Tiwari et al., 1991; Ghugare et al., 1991; Gite and Yadav, 1990; Nag et al., 1988).

\section{Development of hand and pedal operated maize sheller}

Mudgal et al., (1998) reported about the development of hand operated maize dehusker, pedal operated maize dehusker, pedal operated maize dehusker cum- sheller, power operated maize dehusker and power operated maize dehusker-sheller at MPUAT, Udaipur. Dehusker unit was made using a pair of rubber and spirally welded MS rod on steel rollers. Some serrated blades were used lengthwise to facilitate the dehusking. A combined unit for dehusking-shelling in one cylinder was tried by using half of the cylinder length with rasp bars and the other with rubber strips in octagonal cylinder to act as dehusker and sheller, respectively.

\section{Materials and Methods}

\section{Experimental variables for study}

To assess ergonomical performance of pedal operated rotary maize sheller, the trial was conducted on test set-up for measuring psycho-physical responses, overall discomfort rating and body part discomfort score experienced.

\section{Experimental variables for study}

To assess ergonomical performance of existing hand operated rotary maize sheller, the trial was conducted on test set-up for measuring physiological and psychological 
responses, overall discomfort rating and body part discomfort score experienced.

\section{Selection of subjects}

The major thrust of this study was to select female agricultural workers to operate hand and pedal operated rotary maize sheller. As per (Gite, 1997) and (Gite and Agrawal, 2004) select six female agricultural workers from an average of above recorded anthropometric data was selected for better result.

After selecting the female for the study mean age, stature, weight and BMI were measured.

Body Mass Index $\left(\mathrm{kg} \mathrm{m}^{-1}\right)=$ Weight, $\mathrm{kg} /$ $(\text { Height })^{2}, \mathrm{~m}$

\section{Selection of Subjects}

The major thrust of this study was to select female agricultural workers to operate hand and pedal operated rotary maize sheller.

As per (Gite, 1997) and (Gite and Agrawal, 2004) select six female agricultural workers from an average of above recorded anthropometric data was selected for better result.

\section{Preliminary preparation for evaluation of} pedal operated rotary maize sheller

After harvesting, maize cobs were dried on concrete floor in the sun for 10 days. The dried cobs were de-husked manually and damaged or irregular shaped maize cobs, which likely to interfere with the smooth feeding of the cobs during shelling operation were removed out of the complete lot of maize cobs earmarked for conducting continue simulation studies.

Everyday three female subjects were asked to report in the lab. The trials were conducted between 9.00 A.M. to 4.00 P. M. The dry bulb temperature, wet bulb temperature and relative humidity were measured during each trial in the field by using thermo-hygrometer.

It was ensured that they were in well health, sound sleep in the previous night, had a normal breakfast about 2 hours before the trial and were free from stimulants like beverages, cigarettes, tobacco etc. and had not performed any severe exercise before the experiment.

Preliminary trials conducted with six female agricultural workers on pedal operated rotary maize sheller. Female agricultural workers were first asked to operate the machine by pedal and each woman was replicated thrice.

\section{Ergonomical evaluation of pedal operated mechanism}

\section{Evaluation of machine}

Experiments were conducted on newly developed pedal operated mechanism for existing hand operated maize sheller. The six female agricultural workers worked on pedal operated maize sheller. A first female works 15 min duration for a first combination at the same time other women will take a rest; similar steps were followed for every treatment. Every treatments were carried out and females heart rate, oxygen consumption rate, overall discomfort rating and body part discomfort score was recorded.

The study was conducted in random order to avoid biasness in observation. The seat height (690 $\mathrm{mm})$, pedal length $(180 \mathrm{~mm})$ and backrest height $(400 \mathrm{~mm})$ were set as per the requirement of that trial.

The tests were conducted in a field of Agronomy at 8.00 am to $4 \mathrm{pm}$. The dry bulb temperature was $20 \pm 10^{\circ} \mathrm{C}$ and relative humidity was $30 \pm 10 \%$ at morning hour and 
temperature was 30 to $42^{\circ} \mathrm{C}$ and relative humidity was $12 \pm 5 \%$ at afternoon hour. The other conditions for the test were as follows:

The saddle height was kept in such a way that the subject's legs were almost straight at knee when the pedal was at the distal position.

The subject was asked to pedal the machine at a pedaling rate of 78 RPM indicated through sense of hearing and visual signals of metronome and the workload automatically increased as per the protocol.

The age predicted maximum heart rate (HR max) of each subject was determined using the equation " $\mathrm{HR}_{\max }=220$ - age in years ".

The target heart rate was approximated as 75 $\%$ of the age predicted maximum heart rate $\left(\mathrm{HR}_{\max }\right)$ as determined from the above equation (Shephard, 1980).

The complete test was of 15 min duration, however, it was terminated at a stage when heart rate of the subject reached the target heart rate and the subject was not able to maintain the recommended pedalling rate and she reached volitional exhaustion. However, to have a better correlation of heart rate, oxygen consumption rate and workload, the subjects were encouraged to continue the test for the complete duration. The values of physiological responses for last 15 second of a particular stage were taken as representative values for that workload.

\section{Psychophysical responses}

Psychophysical responses of operation are expressed in terms of overall discomfort rating and body part discomfort score.

\section{Overall discomfort rating}

For the assessment of overall discomfort rating a 10 - point Visual Analogue
Discomfort (VAD) scale proposed by Legg and Mahanty (1985) was used (Fig.1). At the end of each trial subjects was asked to indicate their overall discomfort rating. Overall discomfort rating given by each of the subjects were added and averaged to get the mean rating (Fig. 2).

\section{Body part discomfort score during hand cranking}

To measure body part discomfort score Corlett and Bishop (1976) technique was used. In this technique the subject's body is divided into 27 regions figure. For evaluating body part discomfort score, a figure having different numbered body parts as shown in figure was presented in front of the subject. The subject was asked to mention all body parts with discomfort starting with the most painful, the next most painful and so on till no further areas were reported. The number of different groups of body parts, which were identified from extreme discomfort to nodiscomfort represented the number of intensity levels of pain experienced (Fig. 3).

The rating was assigned to those categories in an arithmetic order, viz., $1^{\text {st }}$ category (body parts experiencing maximum pain) rating was allotted as ' 6 ' and for $2^{\text {nd }}$ category (body parts experiencing next maximum pain) rating was allotted as ' 5 ' and so on, finally for the $6^{\text {th }}$ category (body parts experiencing least pain) rating was allotted as ' 1 '. It was found that the number of intensity levels of pain experienced by different subjects might vary. For example, if one subject has experienced " 4 ' categories, $1^{\text {st }}$ category rating was allotted as ' 6 ' and for $2^{\text {nd }}$ category rating was allotted as ' 4.5 ' and so on for fourth category rating was allotted as 1.5 . In order to get an ideal analysis of results after ranking, each data was marked in a numerical way. The body part discomfort score of all the subjects were added and averaged to get mean score. 
Performance evaluation of pedal operated rotary maize sheller

To evaluate the performance of pedal operated maize sheller same procedure described as discussed below. The operators were given the tips, information and working of the machine for $20 \mathrm{~min}$ before starting the actual trials.

In each trial machine was operated for $15 \mathrm{~min}$ to shell the maize cobs with moisture content of 12 to $18 \%$.

The weight of detached kernels collected in the tray and from the collection unit, spread kernels, damaged kernels and completely shelled cob was recorded after each trial to determine shelling efficiency, total output capacity.

\section{Shelling efficiency}

The shelling efficiency is the ratio of thresher grains collected in two outlets per unit time to the total grain input per unit time. Shelling efficiency is defined as the mass of the kernels actually shelled to the total mass of kernels on the ear before shelling.

shellingefficiency, $\%=\frac{\mathrm{W}_{1}-\mathrm{W}_{2}}{\mathrm{~W}_{1}} \times 100 \%$

Where,

W1=Total weight of maize cobs for shelling in sample, gm.

$\mathrm{W}_{2}=$ Final weight of grains attached with shelled cobs, gm.

\section{Output capacity}

At each treatments shelled grains weight and the shelling time ( $\mathrm{T})$ in seconds were recorded, then the output capacity $\left(\mathrm{kg} \mathrm{h}^{-1}\right)$ was calculated as follows;

Output capacity $=\frac{\mathrm{M}_{\mathrm{t}} \times 3600}{\mathrm{~T}(\mathrm{sec})} \times 100 \%$

Where,

$\mathrm{M}_{\mathrm{t}}=$ Mass of total grains in the sample, $10 \mathrm{~kg}$

$\mathrm{T}=$ Shelling time, $\mathrm{sec}$

\section{Results and Discussion}

\section{Ergonomical evaluation of hand operated rotary maize sheller}

The ergonomic evaluation of the existing hand operated rotary maize sheller was carried out to evaluate drudgery in operation and subsequently to modify the existing machine.

During evaluation of the maize sheller, physical, physiological and psychological values of the subjects were studied. In total six subjects were selected for the study. The subjects were selected (Gite and Singh, 1997 and Gite and Agrawal, 2004) from an average of recorded anthropometric data.

Female agricultural workers for ergonomical evaluation

In present study six female agricultural workers of Akola district were selected they work on hand operated maize sheller.

The mean $( \pm$ S.D $)$ values of age, weight and stature of six female workers $(\mathrm{N}=6)$ selected for the study were $30.66 \pm 2.16$ years, $56.5 \pm$ $5.46 \mathrm{~kg}$, and $1495 \pm 42.66 \mathrm{~mm}$ respectively. According to the Rajshekhar M., et al., (2015) these were the normal resting heart rates of females in the age range of 25-35 years which indicates free from any health problem. 


\section{Psychophysical evaluation}

The psychophysical responses of the subject were also evaluated during cob shelling operation. The percentage of oxygen consumption rate, cardiac cost of operation and energy expenditure rate were determined and depicted in Appendix-E.

\section{Body part discomfort score}

\section{Effect of pedal length, sitting height and backrest height on body part discomfort score of subjects}

The table 5.24 reveled the combine effect of pedal length $160 \mathrm{~mm}$ and sitting height 690 $\mathrm{mm}$ at three different backrest height i.e. 200, 400 and $600 \mathrm{~mm}$ on body part discomfort score of the subject and observed as 13.67, 10.33 and 16.67 respectively. The analysis showed that body part discomfort score of the subject decreases with increase in backrest height up to $400 \mathrm{~mm}$ and increases slightly with increase in backrest height from 400 to $600 \mathrm{~mm}$. At sitting height 710 and $730 \mathrm{~mm}$, body part discomfort score decreases by 44.8 $\%$ and $18.84 \%$, respectively with increase in backrest height up to $400 \mathrm{~mm}$ and further it increase with $18.9 \%$ and $17.39 \%$ with increase in backrest height up to $600 \mathrm{~mm}$.

At backrest height $200 \mathrm{~mm}$ and pedal length $160 \mathrm{~mm}$ the values of body part discomfort score increases with increase in sitting height from 690 to $710 \mathrm{~mm}$ and decreases with increase in sitting height up to $730 \mathrm{~mm}$. However, at backrest height $400 \mathrm{~mm}$ and 600 $\mathrm{mm}$, the reverse trend was observed i.e. body part discomfort score decreases with $14.52 \%$ and $37.01 \%$ with increase in sitting height from 690 to $710 \mathrm{~mm}$ then increases by 30.23 $\%$ and $28.57 \%$ with increase in sitting height up to $730 \mathrm{~mm}$.

The minimum value of body part discomfort score for the pedal length of $160 \mathrm{~mm}$ was observed at sitting height $710 \mathrm{~mm}$ and backrest height $400 \mathrm{~mm}$ while maximum value was observed at sitting height $690 \mathrm{~mm}$ and backrest height $600 \mathrm{~mm}$.

The combine effect of pedal length $180 \mathrm{~mm}$ and sitting height $690 \mathrm{~mm}$ at three different backrest heights i.e. 200, 400 and $600 \mathrm{~mm}$ on body part discomfort score of the subject observed to be 13.83, 11.67 and 12.00 respectively. The analysis showed that the values of body part discomfort score of the subject decreases by $15.61 \%$ with increase in backrest height up to $400 \mathrm{~mm}$ and increases by $2.8 \%$ with increase in backrest height from 200 to $600 \mathrm{~mm}$.

At sitting height $710 \mathrm{~mm}$ similar trend as that of $690 \mathrm{~mm}$ was observed however, at sitting height $730 \mathrm{~mm}$ values of body part discomfort score decreases by $58.8 \%$ with increasing backrest height from 200 to $600 \mathrm{~mm}$.

At pedal length $180 \mathrm{~mm}$ with backrest height $200 \mathrm{~mm}$, the values of body part discomfort score decreases by $2.38 \%$ with increase in sitting height from 690 to $730 \mathrm{~mm}$. However, at backrest height $400 \mathrm{~mm}$ the values decreases by $40.01 \%$ with increase in sitting height up to $710 \mathrm{~mm}$ then increases by 59.57 $\%$ with increase in sitting height from 690 to $730 \mathrm{~mm}$.

At backrest height $600 \mathrm{~mm}$ similar trend as that of $400 \mathrm{~mm}$ was observed. The minimum value of body part discomfort score for the pedal length of $180 \mathrm{~mm}$ was observed at sitting height $710 \mathrm{~mm}$ and backrest height 400 $\mathrm{mm}$ while maximum was observed at sitting height $690 \mathrm{~mm}$ and backrest height $200 \mathrm{~mm}$.

The combine effect of pedal length $200 \mathrm{~mm}$ and sitting height $690 \mathrm{~mm}$ at three different backrest heights i.e. 200, 400 and $600 \mathrm{~mm}$ on body part discomfort score of the subject observed to be $16.50,14.50$ and 18.33. The analysis showed that there was decrease in 
body part discomfort score of the subject by $12.12 \%$ with increase in backrest height up to $400 \mathrm{~mm}$ and then increases with increase in backrest height up to $600 \mathrm{~mm}$.

At sitting height $710 \mathrm{~mm}$ similar trend as that of sitting height $690 \mathrm{~mm}$ was observed. However, at sitting height $730 \mathrm{~mm}$ body part discomfort score values decreases by $44.34 \%$ with increase in backrest height from 200 to $600 \mathrm{~mm}$. At pedal length $200 \mathrm{~mm}$ with backrest height $200 \mathrm{~mm}$ the values of body part discomfort score increases by $19.21 \%$ with increase in sitting height from 690 to 710 $\mathrm{mm}$ and decreases by $33.04 \%$ with increase in sitting height up to $730 \mathrm{~mm}$ at backrest height $200 \mathrm{~mm}$. However, at backrest height $400 \mathrm{~mm}$ the values decrease with increasing sitting height from 690 to $730 \mathrm{~mm}$. At backrest height $600 \mathrm{~mm}$, similar trend was observed as that of backrest height $400 \mathrm{~mm}$.

The minimum value of body part discomfort score for the pedal length of $200 \mathrm{~mm}$ was observed at sitting height $730 \mathrm{~mm}$ and backrest height $600 \mathrm{~mm}$ while maximum value was observed at sitting height $710 \mathrm{~mm}$ and backrest height $200 \mathrm{~mm}$.

Table 5.24 revealed that the minimum value of body part discomfort score was observed at the combination of sitting height 710 and backrest height $400 \mathrm{~mm}$ at pedal length 180 while maximum value was observed at combination of sitting height $690 \mathrm{~mm}$ and backrest height $200 \mathrm{~mm}$ at pedal length 200 $\mathrm{mm}$.

It might be due to the fact that at above said combination the thigh-torso angle was less due to this workers fill discomfort and fatigue in less time. This is supported by Gailyn et al., (2006). The minimum value observed at pedal length $160 \mathrm{~mm}$ was $26.14 \%$ and 20.44
$\%$ higher than the minimum value observed with pedal length $180 \mathrm{~mm}$ and pedal length $200 \mathrm{~mm}$, respectively. Similarly, the maximum values of body part discomfort score at pedal length $200 \mathrm{~mm}$ was also 17.99 $\%$ and $42.22 \%$ higher than the values observed with pedal length 160 and $180 \mathrm{~mm}$, respectively.

The interaction effect of pedal length, sitting height and backrest height not evidently differ i.e. non-significant at $5 \%$ level of significance.

These results of body part discomfort score of female agricultural workers alsoco-relates with the findings by (Lollgen et al., 1980).

\section{Overall discomfort rating of subjects}

\section{Effect of pedal length, sitting height and backrest height on overall discomfort rating of the subjects}

The effect of pedal length, sitting height and backrest height on the overall discomfort rating of the selected subject for pedal operated shelling mechanism was evaluated and results depicted in Table 5.28.

The combine effect of pedal length $160 \mathrm{~mm}$ and sitting height $690 \mathrm{~mm}$ at three different backrest heights i.e. 200, 400 and $600 \mathrm{~mm}$ overall discomfort rating of the subject observed to be 3.08, 4.27 and 3.85.

The analysis showed that overall discomfort rating of the subject increases by $38.63 \%$ with increase in backrest height up to $400 \mathrm{~mm}$ and decreases slightly by $9.83 \%$ with increase in backrest height from 400 to 600 $\mathrm{mm}$. Reverse trend was observed at sitting height $710 \mathrm{~mm}$ as that of sitting height 690 $\mathrm{mm}$. 
Fig.1 Visual analogue discomfort (VAD) scale
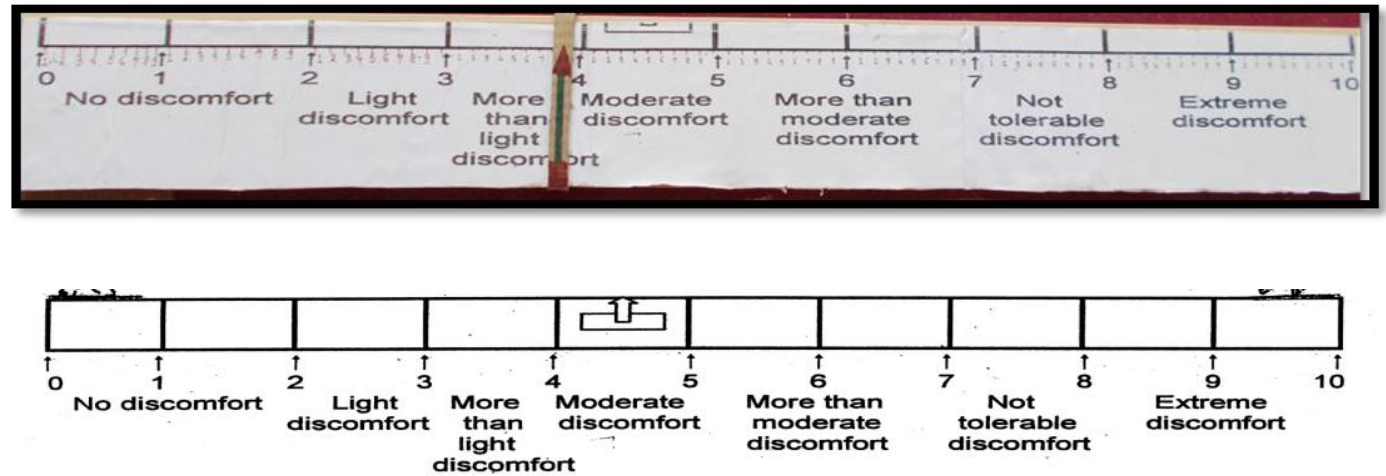

Fig.2 Visual Analog Discomfort (VAD) scale for assessment overall body discomfort rating

Fig.3

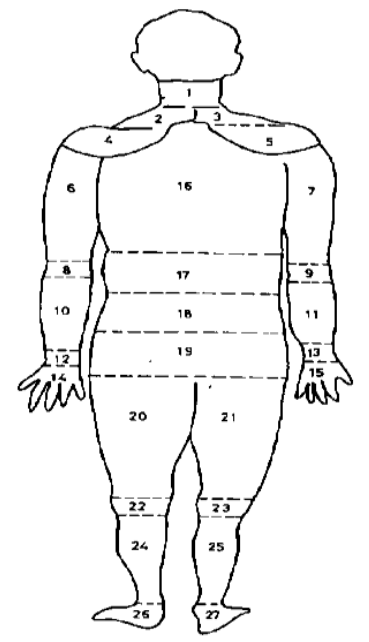

neck

clavicle left

CLAVICLE RIGHT

4. LEFT SHOULDER
5. RIGHT SHOULDER

7. RIGHT ARM

LEFT ELBOW

. LEFT FOAEARM

19. RIGMT FOREARM

12. REFT WAIST

15. RIGMT PALM

MID BACK

a. LOWEA BACK

19. BUTTOCKS

20. LEFY THIGH

2. LEFT KNEE

RIGHT LEC

26. LEFT FOOT

Fig. Regions for evaluating body part discomfort score by using

\section{Corlletand Bishop technique}

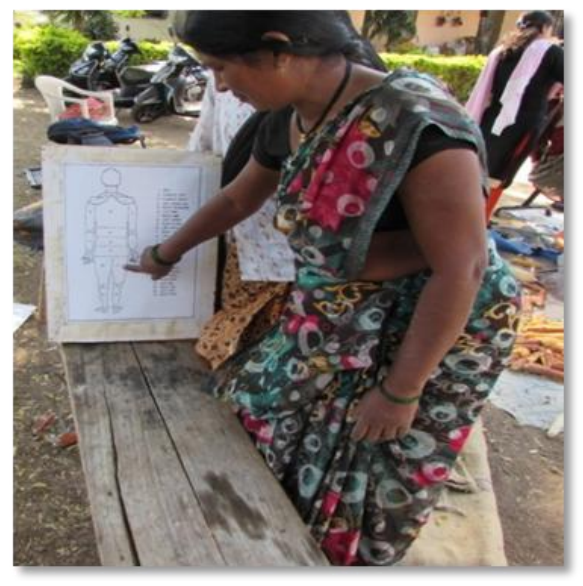

Plate. Body part discomfort score

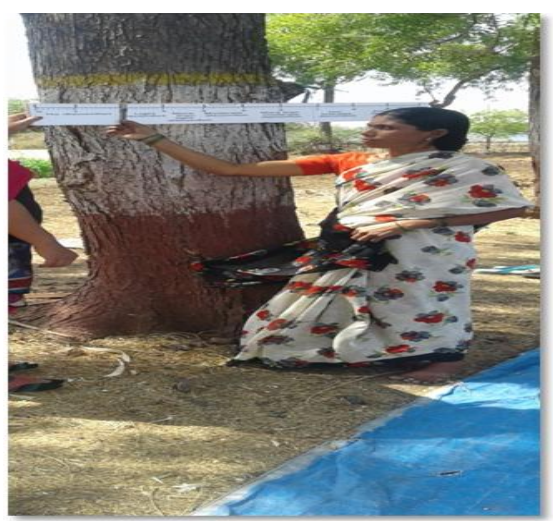

Plate. Visual analog discomfort scale 

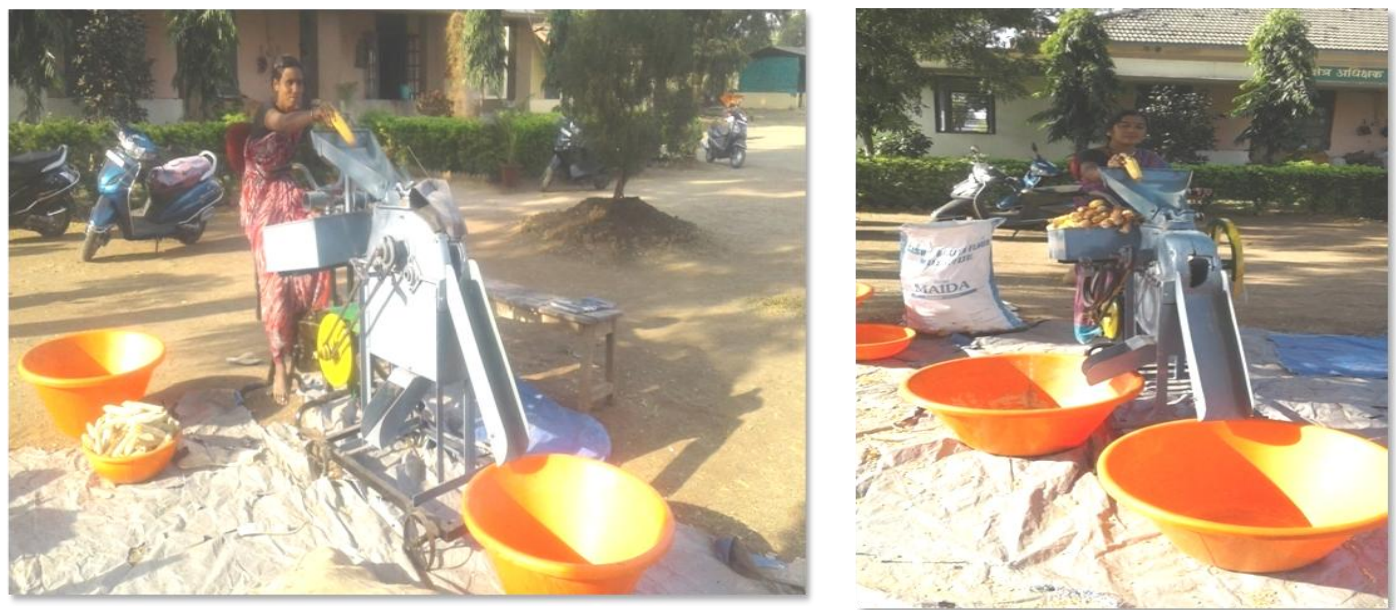

Plate . Evaluation of modified maize sheller

Experimental variables for study

\begin{tabular}{|c|c|c|c|}
\hline Sr. No & Variables & Levels & Symbols \\
\hline \multicolumn{4}{|c|}{ Independent } \\
\hline 1 & Pedal length, mm & 3 & $\mathrm{P} 1, \mathrm{P} 2, \mathrm{P} 3$ \\
\hline 2 & Sitting height, $\mathrm{mm}$ & 3 & $\mathrm{~S} 1, \mathrm{~S} 2, \mathrm{~S} 3$ \\
\hline 3 & Backrest height,mm & 3 & $\mathrm{~B} 1, \mathrm{~B} 2, \mathrm{~B} 3$ \\
\hline \multicolumn{4}{|c|}{ Dependent } \\
\hline \multicolumn{4}{|c|}{ b) Psychological responses } \\
\hline 4 & Overall discomfort rating (ODR) & - & \\
\hline 5 & Body part discomfort score (BPDS) & - & \\
\hline 6 & Cardiac cost of operation, (beats $\mathrm{kg}^{-1}$ ) & & \\
\hline 7 & Energy expenditure rate, $\left(\mathrm{kJ} \min ^{-1}\right)$ & & \\
\hline \multicolumn{4}{|c|}{ c) Performance parameters } \\
\hline 8 & Shelling efficiency, $(\%)$ & - & \\
\hline 9 & Output capacity, $\left(\mathrm{kg} \mathrm{h}^{-1}\right)$ & - & \\
\hline
\end{tabular}

Performance evaluation of modified pedal operated maize sheller

\begin{tabular}{|c|c|c|}
\hline Subjects & Output capacity, $\mathbf{~ k g ~ h}^{\mathbf{- 1}}$ & Shelling efficiency, \% \\
\hline S1 & 218.64 & 97.89 \\
\hline S2 & 222.83 & 97.52 \\
\hline S3 & 220.00 & 98.35 \\
\hline S4 & 215.56 & 98.11 \\
\hline S5 & 219.6 & 98.57 \\
\hline S6 & 222.00 & 98.07 \\
\hline Sean & 219.68 & 98.09 \\
\hline CV\% & 2.46 & 0.364 \\
\hline
\end{tabular}


Table.1 Effect of pedal length, sitting height and backrest height on body part discomfort score of subjects

\begin{tabular}{|c|c|c|c|c|c|c|c|c|c|c|}
\hline & & & & Body & part dis & comfor & score & & & \\
\hline & & & & & edal leı & gth, mI & & & & \\
\hline & & & 160 & & & 180 & & & 200 & \\
\hline & & & & & Sittin & heigh & $\mathbf{m m}$ & & & \\
\hline Backrest & & 690 & 710 & 730 & 690 & 710 & 730 & 690 & 710 & 730 \\
\hline height, & 200 & 13.67 & 16.00 & 14.17 & 13.83 & 13.67 & 13.50 & 16.50 & 19.67 & 13.17 \\
\hline & 400 & 10.33 & 8.83 & 11.50 & 11.67 & 7.00 & 11.17 & 14.50 & 11.17 & 10.83 \\
\hline & 600 & 16.67 & 10.50 & 13.50 & 12.00 & 8.33 & 8.50 & 18.33 & 11.83 & 7.33 \\
\hline & & & & & $\mathrm{Fac}$ & & & & & \\
\hline & & & & & A* & $* \mathrm{C}$ & & & & \\
\hline F-test & & & & & $\mathrm{N}$ & & & & & \\
\hline SE (m) & & & & & & & & & & \\
\hline CD \% & & & & & & & & & & \\
\hline
\end{tabular}

Where, S-significant and NS-non-significant

Table.2 Effect of pedal length, sitting height and backrest height on overall discomfort rating of the subjects

\begin{tabular}{|c|c|c|c|c|c|c|c|c|c|c|}
\hline & \multicolumn{10}{|c|}{ Overall discomfort rating } \\
\hline & \multicolumn{10}{|c|}{ Pedal length, mm } \\
\hline & \multicolumn{4}{|c|}{160} & \multicolumn{3}{|c|}{180} & \multicolumn{3}{|c|}{200} \\
\hline & & & & & Sitt & g heig & $\mathbf{m m}$ & & & \\
\hline \multirow{6}{*}{$\begin{array}{l}\text { Backrest } \\
\text { height, } \\
\text { mm }\end{array}$} & & 690 & 710 & 730 & 690 & 710 & 730 & 690 & 710 & 730 \\
\hline & 200 & 3.08 & 4.36 & 3.31 & 3.53 & 4.53 & 3.36 & 3.06 & 4.11 & 3.29 \\
\hline & 400 & 4.27 & 3.49 & 4.45 & 4.1 & 2.88 & 4.73 & 4.21 & 3.11 & 4.65 \\
\hline & 600 & 3.85 & 3.54 & 4.08 & 3.83 & 3.59 & 4.16 & 3.94 & 3.50 & 4.16 \\
\hline & \multicolumn{10}{|c|}{ Factors } \\
\hline & \multicolumn{10}{|c|}{$A * B * C$} \\
\hline F-test & \multicolumn{10}{|c|}{$\mathrm{S}$} \\
\hline SE $(\mathbf{m})$ & \multirow{2}{*}{\multicolumn{10}{|c|}{0.20}} \\
\hline CD \% & 0.56 & & & & & & & & & \\
\hline
\end{tabular}

Where, S-significant and NS-non-significant

However, at sitting height $730 \mathrm{~mm}$ the values of overall discomfort rating increases by $34.44 \%$ increasing from backrest height 200 to $400 \mathrm{~mm}$ and then decreases by $8.31 \%$ which increase in backrest height up to 600 $\mathrm{mm}$.

At pedal length $160 \mathrm{~mm}$ the values of overall discomfort rating increases by $41.55 \%$ with increase in sitting height from 690 to $710 \mathrm{~mm}$ and decreases by $24.08 \%$ with increase in sitting height $730 \mathrm{~mm}$ up to backrest height $200 \mathrm{~mm}$. However, at backrest height $400 \mathrm{~mm}$ and $600 \mathrm{~mm}$, the reverse trend was observed i.e. overall discomfort rating decreases by $18.26 \%$ and $8.05 \%$ with increase in sitting height from 690 to $710 \mathrm{~mm}$ then increases by $27.50 \%$ and $15.25 \%$ with increase in sitting 
height from 710 to $730 \mathrm{~mm}$. The minimum value of overall discomfort rating for the pedal length of $160 \mathrm{~mm}$ was observed at sitting height $690 \mathrm{~mm}$ and backrest height 200 $\mathrm{mm}$ while maximum was observed at sitting height $730 \mathrm{~mm}$ and backrest height $400 \mathrm{~mm}$.

The statistical analysis of the combine effect of pedal length $180 \mathrm{~mm}$ and sitting height 690 $\mathrm{mm}$ at three different backrest heights i.e. 200,400 and $600 \mathrm{~mm}$ on overall discomfort rating of the subject observed to be $3.53,4.1$ and 3.83 .

The analysis showed that there was increase by $16.14 \%$ in overall discomfort rating of the subject with increase in backrest height up to $400 \mathrm{~mm}$ and decreases by $6.58 \%$ with increase in backrest height from 400 to 600 $\mathrm{mm}$. At sitting height $710 \mathrm{~mm}$ the reverse trend was observed as that of sitting height $690 \mathrm{~mm}$. However, at sitting height $730 \mathrm{~mm}$ the values of overall discomfort rating increases by $40.77 \%$ with increase in sitting height up to $690 \mathrm{~mm}$ and then decreases by $12.05 \%$ up to $730 \mathrm{~mm}$.

At pedal length $180 \mathrm{~mm}$ the values of overall discomfort rating increases by $28.32 \%$ with increase in sitting height from 690 to $710 \mathrm{~mm}$ and decreases by $25.82 \%$ with increase in sitting height up to $730 \mathrm{~mm}$ at backrest height $200 \mathrm{~mm}$. However, at backrest height $400 \mathrm{~mm}$ and at backrest height $600 \mathrm{~mm}$ reverse trend was observed as that of backrest height 200 $\mathrm{mm}$. The minimum value of overall discomfort rating for the pedal length of 180 $\mathrm{mm}$ was observed at sitting height $710 \mathrm{~mm}$ and backrest height $400 \mathrm{~mm}$ while maximum was observed at sitting height $730 \mathrm{~mm}$ and backrest height $400 \mathrm{~mm}$.

The statistical analysis of the combine effect of pedal length $200 \mathrm{~mm}$ and sitting height 690 $\mathrm{mm}$ at three different backrest height i.e. 200, 400 and $600 \mathrm{~mm}$ on overall discomfort rating of the subject observed to be 3.06, 4.21 and 3.94. The analysis showed that overall discomfort rating of the subject increases by $37.58 \%$ with increase in backrest height from 200 to $400 \mathrm{~mm}$ and decreases by $6.41 \%$ shortly with increasing backrest height from 400 to $600 \mathrm{~mm}$.

At sitting height $710 \mathrm{~mm}$ reverse trend was observed as that of sitting height $690 \mathrm{~mm}$. However, at sitting height $730 \mathrm{~mm}$ overall discomfort rating increases by $41.33 \%$ with increase in backrest height from 200 to 400 $\mathrm{mm}$ and decreases $10.53 \%$ slightly with increasing backrest height up to $600 \mathrm{~mm}$. At pedal length $200 \mathrm{~mm}$ the values of overall discomfort rating increases by $34.31 \%$ with increase in sitting height from 690 to $710 \mathrm{~mm}$ and decreases by $19.95 \%$ with increase in sitting height up to $730 \mathrm{~mm}$ at backrest height $200 \mathrm{~mm}$.

However, at backrest height $400 \mathrm{~mm}$ and 600 $\mathrm{mm}$ reverse trend was observed as that of backrest height $200 \mathrm{~mm}$. The minimum value of overall discomfort rating for the pedal length $200 \mathrm{~mm}$ was observed at sitting height $690 \mathrm{~mm}$ and backrest height $200 \mathrm{~mm}$ while maximum was observed at sitting height 730 $\mathrm{mm}$ and backrest height $400 \mathrm{~mm}$. The minimum value observed at pedal length 160 mm was $6.94 \%$ and $0.65 \%$ higher than the minimum value observed with pedal length $180 \mathrm{~mm}$ and pedal length $200 \mathrm{~mm}$, respectively. Similarly, the maximum values of overall discomfort rating at pedal length $180 \mathrm{~mm}$ was also $6.29 \%$ and $1.72 \%$ higher than the values observed with pedal length 160 and $200 \mathrm{~mm}$, respectively.

It was also observed that the maximum value of overall discomfort rating was at sitting height $690 \mathrm{~mm}$ and backrest height $200 \mathrm{~mm}$ with pedal length $180 \mathrm{~mm}$ because seat type and sitting discomfort affects the overall discomfort score. 
The interaction effect of pedal length, sitting and backrest height on overall discomfort rating found statistically significant having SE (m) value was 0.202 and $\mathrm{CD} \% 0.565$. In the present study, initially the ODR increases with increasing in sitting height and the same trend was observed by Pandolf and Noble (1973) due to sensation of strain. Further workload studied that the higher in comparison to the present study, the subject might have felt less strain in the local muscles because of reduced force application at a given work in pedaling mechanism.

\section{Performance evaluation of modified pedal operated maize sheller}

Experiments were carried out to evaluate the pedal operated rotary maize sheller in terms of output capacity, shelling efficiency. In the evaluation of six female workers operated the machine in specified interval of testing at pedal length $180 \mathrm{~mm}$, sitting height $690 \mathrm{~mm}$ and backrest height $400 \mathrm{~mm}$.

\section{Performance evaluation of modified pedal operated maize sheller}

For the assessment of machine following parameters were consider viz shelling efficiency $(\%)$, output capacity $\left(\mathrm{kg} \mathrm{h}^{-1}\right)$ and details were given in Appendix-K.

Table 5.44 revealed the output capacity, shelling efficiency of pedal operated maize sheller was found as $220 \mathrm{~kg} \mathrm{~h}^{-1}$, and $98.09 \%$, respectively. Similar, findings were reported by Mahatle (2007) during ergonomic study carried out on different types of maize sheller. In conclusions, the psychophysical responses i.e. body-part discomfort score and overall discomfort score were found to be $7,2.88$ on pedal operated maize sheller.

The body discomfort was mainly experienced at left and right knee, left and right leg, and left and right thigh

According to Visual Analogue Discomfort scale the category of the pedal operated maize sheller was found to be "light discomfort".

Shelling efficiency and output capacity were found to be $220 \mathrm{~kg} \mathrm{~h}^{-1}$ and $98.09 \%$ on hand operated maize sheller.

\section{References}

Astrand, P. (1953). Study of bicycle modification using a motor driven treadmill-bicycle ergometer. Arbeitsphysiologie, 15: 23-32.

Brouha, L. (1967). Physiology in Industry. Pergamon Press, Oxford.

Chandel, R. (2005). Studies on ergonomic aspects of scythe in harvesting of Berseem (Trifolium alexandrinum). M.E thesis submitted to Punjab Agricultural University, Ludhiana.

Grandjean, E. (1982). Fitting the task to the man - An ergonomic approach. Taylor and Francis Ltd., London.

Nag PK; Goswami A; Ashtekar S; Pradhan CK. 1988. Ergonomics in sickle operation. Appl. Ergon., 19(3), 233-239.

\section{How to cite this article:}

Kanchan V. Gedam and Thakare, S.K. 2019. Physical and Psycho-Physical Characteristics of Female on Developed Pedal Operated Rotary Maize Sheller in Akola Region. Int.J.Curr.Microbiol.App.Sci. 8(06): 1835-1846. doi: https://doi.org/10.20546/ijcmas.2019.806.219 